\title{
分析命題の論理的情報について
}

永井成男

\section{On the Logical Information of Analytic Sentence}

Shigeo Nagai

In this paper I shall define the concept logical information distinguished from a customary concept (semantic) information, which is called "factual information" in the paper. In accordance with the contemporary theory of semantic information, if $\mathrm{i}$ is an analytic sentence, then i conveys no information. It means that

$$
\inf (i)=-\log m(i)=0
$$

where $\mathrm{i}$ is an analytic sentence and inf is the measure of information. According to our intuition, however, it seems that most analytic sentences convey much more information than "A is A", which is a trivial analytic sentence or tautology. I shall give only one example here.

1. Man is man. $\left(\mathrm{S}_{1}\right)$

2. Man is a rational animal. $\left(\mathrm{S}_{2}\right)$

Let us suppose that the both sentences $S_{1}$ and $S_{2}$ are analytic. Then $\mathrm{S}_{2}$ has the same intention, and hence conveys the same amounts of factual information, as $\mathrm{S}_{1}$, whereas $\mathrm{S}_{2}$ has the more complicated intensional structure, and hence conveys much larger amounts of logical information, than $\mathrm{S}_{\mathbf{1}}$.

\section{1. 序*}

常識によれば, 数学の知識は経験科学と同様にわれわれに現実の世界について の新しい情報を伝えてくれる。たとえば, $2+3=5$ という算術の知識を学ぶな らば，現実の世界についての新しい情報を得たことになる。この常識に最も近い 素朴な反映論によれば，数学と経験科学の知識は本質的には同一であって，いず 
れの認識も外界の存在が意識に反映されたものである。ただ数学の知識は経験科 学の知識よりもいっそう一般的・抽象的であるといら程度の相違があるにすぎな い。したがって, 数学の法則は現実の世界の因果的構造を示す経験科学の法則と 本質的には同一であり，ただ，さらに一段と一般化・抽象化がすすめられている というにすぎない。形式論理学—したがって記号論理学——の論理法則もまた 数学の法則と本質的に同一であって，ただいっそう一般的・抽象的である点で比 較的な相違があるにすぎない。数学や形式論理学の認識をもふくめて, あらゆる 認識は外界の存在の意識に护ける反映であり, したがって, 認識に和ける真理と は外界の存在とその映像である知識との一致を意味している。この素朴な反映論 によれば, 数学と形式論理学の知識は, 経験科学の知識と本質的には同一な事実 的情報一一現実の世界についての経験的な情報——を伝えることになる。ただ経 験科学よりは数学が, 数学よりは形式論理学が, より少ない事実的情報を伝える という程度上の相違があるにすぎない。

この素朴な反映論的な考方方に対し，カントの先験論の考方方がある。それに よれば形式論理学と数学の知識は本質的に異なる。形式論理学の知識は分析的で あり，結局は「AはAなり」といらトートロジーに帰着するが，数学の知識は分 析的ではなく綜合的である。この点で，現実の世界について事実的情報を伝觉る 経験科学の綜合的認識に類似している。しかし，現実の世界について事実的情報 を得るには，知覚による経験的綜合を要するのでア・プリオリな認識ではない点 で, 数学は経験科学と本質的に異なる。ア・プリオリな認識であるという点で は, むしろ数学は論理学と類似している。数学の知識は現実の世界の形式的構造 についての情報を伝えるのであって，現実の世界を知覚によって認識する際に， 雑多な知覚内容の形を整える形式的な枠組となるもので, 現実の世界の形式的構 造は対象（客観）の側にではなく，主観の側にあるためにそれについての認識が ア・プリオリとなるのである。つまり, 認識の内容である感覚は外から経験によ って与えられるが, 形式は主観（純粋直観浐よび思考）によってア・プリオリに 構成されるのである。だが, 綜合的認識であるから数学は分析的ではなく, 現実 の世界についてア・プリオリなある種の情報を伝えると考觉る。ポアンカレ (1854 
一1912) は，この先験論に立って，もしもラッセル等の論理主義が正しく，数学 は論理学に還元できるとすれば，数学は分析的で「AはAなり」といらトートロ ジーに帰着しなんらの情報をも伝えないつまらぬのになってしまらといって 批判した。

以上の反映論と先験論の主張そのものは，現代の科学哲学の批判に耐え得ない 素朴な思想にすぎないといわねばならない。しかし，その素朴な思想には正しい 意図が全然ふくまれていないというわけではない。この小論は，それらの思想に ふくまれる正しい意図の一側面を現代的に定式化し直す一つの試みである。だ が，反映論については，現代の意味論の真理対応説によって再定式化される側面 が重要であるが，この問題についての考察は，すでに公表しているので，ここで は繰り返さない。(文献7，107-121ページ）

\section{2. 論理的真理の概念}

ある事柄に関して，論理的に可能なすべての場合を挙げ尽くすことを考える。 ある事態が次のように $\mathrm{n}$ 通りの場合に分類されたとしよう。

$$
\theta_{1}, \theta_{2}, \cdots \cdots, \theta_{n}
$$

この分類が論理的可能性のすべてを尽くしているといえるためには，次の二条 件を満たさなければならない。

\section{条件 :}

1. 可能な場合のうち一つは現実の場合である。

2. 可能な場合は互いに論理的に排反（論理的に両立不可能）である。

つまり，可能な $\mathrm{n}$ 通りの場合の中で一つそしてただ一つが現実の場合であると いら条件である。したがって，現実の場合がその中にはいっていなかったり，あ るいは現実の場合がいくつもあったりすれば，この条件は満たされない。たと兄 ば，明日の天候に関して， $\theta_{1}$ : 雨が降る $\theta_{2}$ : 雪が降る $\theta_{3}$ : 風が吹く $\theta_{4}$ : 晴 れであるというょうに分類したとしょう。これは決して明日の天候という事柄 に関する事態の論理的可能性のすべて場合を尽くしてはいない。たと穴，雲り であるという事態は可能な場合であるが，その分類中にふくまれていない。それ 
でそのような不測の事態が起こる可能性があるので条件 1 を満たしていない。ま た明日の天候が風雨であるという事態は， $\theta_{1}$ と $\theta_{3}$ の二つの場合が同時に起こっ たのであるから条件 2 は満たしていない。これに反し，明日の天候を， $\theta_{1}:$ 雨が 降る $\theta_{2}$ : 雨が降らない と分類したとすれば，上の条件は満たされる。このよ うに上の二つの条件を満たしている分類を論理的可能性を尽くしている分類とよ ぶ。この分類は，明日の天候に関するあらゆる可能な事態を挙げ尽くして扣り， 不測の事態は起こりょうがない。ところで,「明日は雨が降るか, あるいは雨が降 らないかどちらかだ」というような天気予報を出したとしょう。この予報は明日 の天候に関して考えられるあらゆる可能な事態のいずれが現実に起こったとして も常に真である。雨が降るという事態が起こっても，雨が降らないという事態が 起こっても常に真である。起こり得るあらゆる事態を論理的に想定して拉いて, そのすべての場合に真となるような予言をすれば，絶対に適中する。しかし，明 日の天気予報ということでわれわれが期待している情報は何も得られない。その 予言は絶対に確実ではあるが，情報としての価值は最低であって，ある意味では 「情報を伝えない」とか「情報量は０である」といってよいだろう。明日の天候 を， $\theta_{1}$ : 雨が降る $\theta_{2}$ : 雨が降らないと分類する代わりに，「明日は雨が降る」

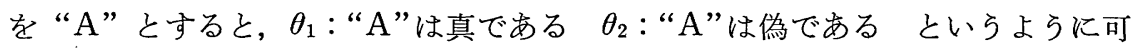

\begin{tabular}{c|c} 
& $\mathrm{A}$ \\
\hline$\theta_{1}:$ & 真 \\
$\theta_{2}:$ & 偽
\end{tabular}

図表 1

\begin{tabular}{|c|c|c|}
\hline & A & $\mathrm{A} \vee \sim \mathrm{A}$ \\
\hline$\theta_{1}:$ & 真 & 真 \\
\hline$\theta_{2}:$ & 偽 & 真 \\
\hline
\end{tabular}

図表 2 能な事態を分類しても同じことである(図表 1 参照)。 すると，「明日は雨が降るか，あるいは雨が降らない かどちらかだ」を“ $\mathrm{A} \vee$ A”と記号化すると，“ $\mathrm{A} \vee$ 〜A”という命題は, 図表 2 の真理表が示しているよ らに，あらゆる可能な事態 $\theta_{1}$ と $\theta_{2}$ に打いて常に真で ある。このよらな性質をもつ命題を分析命題（論理的 に真な命題, 恒真命題など）という。

したがって, 一般に, 任意の言語 $\mathrm{L}$ 命題 $\mathrm{S}$ に関し て恒真（分析的，論理的真）という概念は，次のように定義される。

2. 1 定義 命題 $\mathrm{S}$ は恒真である = df $\mathrm{S}$ はあらゆる可能な事態に和いて常 に真である。 
3. 意味情報の概念

前節において，「分析命題は情報を伝えない」という思想の正確な意味をなる ベく直観的になじみ深い知識とするための説明をしてきたが，本節では，カルナ ップとバー・ヒレルの意味情報理論（theory of semantic information）に基づ いて (文献 $1,2,4,6$ 参照), その直観的な理解をいっそう科学的な明確な概念に よって解明 (explicate) することを試みる。

論理的可能性を尽くしている $\mathrm{n}$ 通りの可能な事態の分類 $\theta_{1}, \theta_{2}, \cdots, \theta_{n}$ に関して, 正規測度関数 (regular measure function) が定義される。 $\mathrm{n}$ 通りの可能な事態 の任意の一つを $\theta_{i}$ とし, $\theta_{i}$ の測度 (測度関数) の $\mathrm{m}\left(\theta_{i}\right)$ は次のように定義され る。

3.1 定義 $\mathrm{m}\left(\theta_{i}\right)$ は正規測度関数である $=\mathbf{d f} \mathrm{m}\left(\theta_{i}\right)$ は次の条件を満たす。

条件: 1. 招の扮のの $\theta_{i}$ について, $\mathrm{m}\left(\theta_{i}\right)$ は正の実数である。

2. すべての $\mathrm{m}\left(\theta_{i}\right)$ の值の和は 1 である。

たとえば，明日の天候に関する命題「雨が降る」の真偽に関する事態を，

$\theta_{1}:\lceil$ 明日雨が降る」は真である。

$\theta_{2}:$ 明日雨が降る」は偽である。

に分類したとしよう。 $\theta_{1}$ の測度 $\mathrm{m}\left(\theta_{1}\right)$ としてある正の定数值を与宎, $\theta_{2}$ の測度 $\mathrm{m}$ $\left(\theta_{2}\right)$ としてある正の実数值を与え，それらの数值の和が 1 になるようにすれば, $\mathrm{m}\left(\theta_{i}\right)$ は正規測度関数である。今, もしも $\theta_{1}$ と $\theta_{2}$ とが等しい重みをもってい る,つまり, 同様の確からしさをもっているとする。かような仮定を無差別原理 (principle of indifference) といらが, この原理を用いると, $\mathrm{m}\left(\theta_{1}\right)=\mathrm{m}\left(\theta_{2}\right)$ と なり, 正規测度関数の定義により, $\mathrm{m}\left(\theta_{1}\right)+\mathrm{m}\left(\theta_{2}\right)=1$ であるから, $\mathrm{m}\left(\theta_{1}\right)=1 / 2$, $\mathrm{m}\left(\theta_{2}\right)=1 / 2$ となる。すなわち，「明日は雨が降る」は真であるという事態 $\theta_{1}$ の測

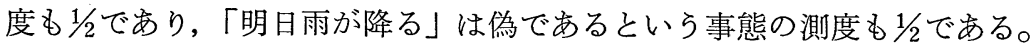

次に，「明日雨が降る」(“A”) といら命題と「明日風が吹く」(“B”) という命 題の真偽に関する論理的可能性は, 図表 3 の真理表が示すように四通りの可能な 事態に分類できる。むろん論理的可能性を尽くしている。ここで, 可能な事態 


\begin{tabular}{cc|cc} 
& $\mathrm{A}$ & $\mathrm{B}$ \\
\hline$\theta_{1}$ & $:$ & 真 & 真 \\
$\theta_{2}$ & $:$ & 真 & 偽 \\
$\theta_{3}$ & $:$ & 偽 & 真 \\
$\theta_{4}$ & $:$ & 偽 & 偽
\end{tabular}

図表 3 $\theta_{1}, \theta_{2}, \theta_{3}, \theta_{4}$ のおの沶のが等しい重みをもっている として無差別原理を用いれば，各 $\theta_{i}$ の測度 $\mathrm{m}\left(\theta_{i}\right)$ は $1 / 4$ である。

以上は可能な事態 $\theta_{i}$ に関して測度関数 $\mathrm{m}\left(\theta_{i}\right)$ を考え てきたが，次には命題 Sに関して測度関数 $\mathrm{m}(\mathrm{S})$ を定 義する。その準備として，まず，Sの真理範囲 (range) といら概念を定義する。

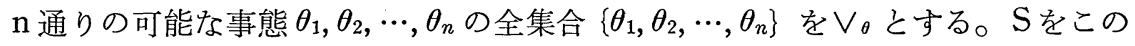
可能な事態の全集合 $V_{\theta}$ に関する一つの命題とするとき，命題 $\mathrm{S}$ を真ならしめる $V_{\theta}$ の元の集合を， $V_{\theta}$ に関する $\mathrm{S}$ の真理範用 $\mathrm{R}(\mathrm{S})$ と定義する。

\section{2 定義 $\mathrm{R}(\mathrm{S})=\mathbf{d f}$ 命題 $\mathrm{S}$ を真ならしめる $\vee_{\theta}$ の元の集合}

実例によって説明する。図表 4 は「明日は雨が降る」(“A”) と「明日は風が吹 く」(“B”)といら命題の真偽の可能性を尽くす分類と, それらの命題を要素とす

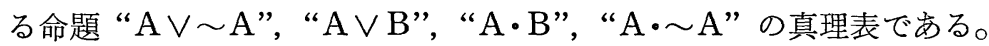

\begin{tabular}{c|cc|c|c|c|c} 
& $\mathrm{A}$ & $\mathrm{B}$ & $\mathrm{A} \vee \sim \mathrm{A}$ & $\mathrm{A} \vee \mathrm{B}$ & $\mathrm{A} \cdot \mathrm{B}$ & $\mathrm{A} \cdots \mathrm{A}$ \\
\hline$\theta_{1}:$ & 真 & 真 & 真 & 真 & 真 & 偽 \\
$\theta_{2}:$ & 真 & 偽 & 真 & 真 & 偽 & 偽 \\
$\theta_{3}:$ & 偽 & 真 & 真 & 真 & 偽 & 偽 \\
$\theta_{4}:$ & 偽 & 偽 & 真 & 偽 & 偽 & 偽
\end{tabular}

図表 4

可能な事態は $\theta_{1}, \theta_{2}, \theta_{3}, \theta_{4}$ の四通りであるから，全集合 $\vee_{\theta}$ は $\left\{\theta_{1}, \theta_{2}, \theta_{3}, \theta_{4}\right\}$ で

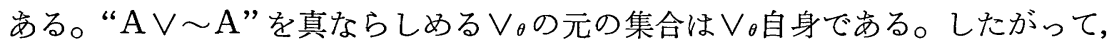
“ $A \vee \sim A "$ の真理範囲 $\mathrm{R}$ (“ $\mathrm{A} \vee \sim \mathrm{A} ”)$ は全集合 $\vee_{\theta}$ である。

3. $3 \mathrm{R}(" \mathrm{~A} \vee \sim \mathrm{A} ")=\vee_{\theta}$ 次に, “ $\mathrm{A} \vee \mathrm{B} ”$ を真ならしめる $\vee_{\theta}$ の元の集合は $\left\{\theta_{1}, \theta_{2}, \theta_{3}\right\}$ であるから,

3. $4 \mathrm{R}\left(“ \mathrm{~A} \vee \mathrm{B}\right.$ ") $=\left\{\theta_{1}, \theta_{2}, \theta_{3}\right\}$

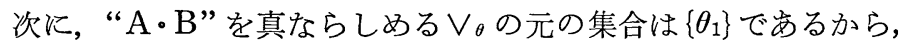

3. $5 \mathrm{R}(“ \mathrm{~A} \cdot \mathrm{B} ")=\left\{\theta_{1}\right\}$

最後に，“A・〜 $\mathrm{A} ”$ を真ならしめる $\vee_{\theta}$ の元はないので, $\mathrm{R}(“ \mathrm{~A} ・ \mathrm{~A} ”)$ は $\theta_{i}$ の 空集合 $\wedge_{\theta}$ である。 
3. $6 \mathrm{R}(“ \mathrm{~A} \cdot \sim \mathrm{A} ")=\wedge_{\theta}$

さて，ここで命題 $\mathrm{S}$ の測度関数 $\mathrm{m}(\mathrm{S})$ を定義する。

3. 6 定義 $\mathrm{m}(\mathrm{S})=\mathbf{d f} \quad \mathrm{R}(\mathrm{S})$ の元 $\theta_{i}$ の測度関数 $\mathrm{m}\left(\theta_{i}\right)$ の值の和 たとえば，分析命題“ $\mathrm{A} \vee \sim \mathrm{A}$ ” の測度 $\mathrm{m}(“ \mathrm{~A} \vee \sim \mathrm{A}$ ”) は 1 である。何故なら ば， $\mathrm{R}(“ \mathrm{~A} \vee \sim \mathrm{A} ”)=\vee_{\theta}$ であり， $\vee_{\theta}$ の元の測度関数の值の和は 1 であるからで ある。一般に分析命題の測度は 1 である。

3. $7 \mathrm{~m}(“ \mathrm{~A} \vee \sim \mathrm{A} ")=1$

矛盾命題 (恒偽命題) “ $\mathrm{A} ・ \mathrm{~A}$ ” の測度 $\mathrm{m}(“ \mathrm{~A} ・ \mathrm{~A} ”)$ はである。何故なら ば, $\mathrm{R}(“ \mathrm{~A} ・ \mathrm{~A} ”)=\wedge_{\theta}$ であり, $\wedge_{\theta}$ の元はないので, $\mathrm{R}(“ \mathrm{~A} ・ \mathrm{~A}$ ”)の元の測度 関数の值の和は 0 とみなされるからである。一般に，矛盾命題の測度は 0 であ る。

3. $8 \mathrm{~m}(" \mathrm{~A} \cdot \sim \mathrm{A} ")=0$

次に “ $\mathrm{A} \vee \mathrm{B} ”$ の測度 $\mathrm{m}(“ \mathrm{~A} \vee \mathrm{B} ”)$ は, $\mathrm{R}(“ \mathrm{~A} \vee \mathrm{B} ”)=\left\{\theta_{1}, \theta_{2}, \theta_{3}\right\}$ の元の測度 関数の値の和 $\mathrm{m}\left(\theta_{1}\right)+\mathrm{m}\left(\theta_{2}\right)+\mathrm{m}\left(\theta_{3}\right)$ であるが, 無差別原理を仮定すれば，各 $\theta_{i}$ の測度 $\mathrm{m}\left(\theta_{i}\right)$ は $1 / 4$ であるから， $\mathrm{m}(“ \mathrm{~A} \vee \mathrm{B}$ ”) $1 / 4+1 / 4+1 / 4$ で $3 / 4$ である。

3. $9 \mathrm{~m}(“ \mathrm{~A} \vee \mathrm{B} ")=3 / 4$

最後に“A・B” の測度 $\mathrm{m}(“ \mathrm{~A} \cdot \mathrm{B}$ ”) は同様に計算して,

$3.10 \mathrm{~m}(“ \mathrm{~A} \cdot \mathrm{B} ")=1 / 4$

上述の命題の測度 $\mathrm{m}(\mathrm{S})$ は, 命題の確証度 (degree of confirmation) として の論理的確率 $\mathrm{c}(\mathrm{S})$ と同じものである。そこで, $\mathrm{c}(\mathrm{S})$ を $\mathrm{m}(\mathrm{S})$ とよって定義す ることができる。

\subsection{1 定義 $\mathrm{c}(\mathrm{S})=\mathbf{d f} \mathrm{m}(\mathrm{S})$}

図表 4 に関し， $\mathrm{m}(\mathrm{S})$ と $\mathrm{c}(\mathrm{S})$ とが同等であることを具体的に説明しよう。 “A $\vee \sim A ”$ は恒真であるからすべての可能な事態において常に真である。つま りそそれが真となる可能な事態の集合一一真理範囲——は全集合 $V_{\theta}$ である。し たがって, $\mathrm{m}(“ \mathrm{~A} \vee \sim \mathrm{A} ”)=1$ であるが, “ $\mathrm{A} \vee \sim \mathrm{A}$ ”は偽となり得ず絶対に真で

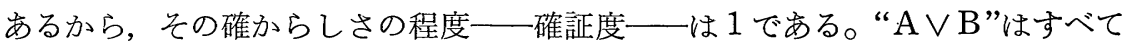
の可能な事態 $\theta_{1}, \theta_{2}, \theta_{3}, \theta_{4}$ のうち三つの場合 $\theta_{1}, \theta_{2}, \theta_{3}$ 飞真となり, $\theta_{4}$ の場合飞偽 
となる。したがって，可能な事態のおの和のが平等の重みをもって和り無差別原

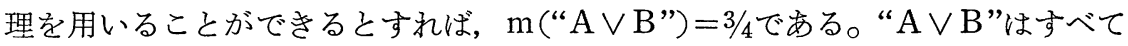

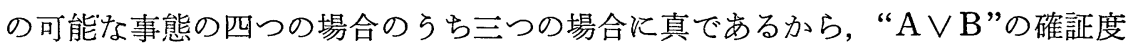

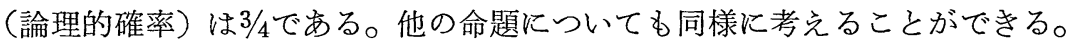

さて，ここで命題の意味情報（semantic information）としての情報量の定義 の問題にはいろうと思うが，シャノン流の通常の工学的な情報理論に和ける情報 量の概念との関係を明らかにする必要から，まず，情報理論の情報量の定義から 考察しょう。たと光ば，「明日は雨が降口。という最後の一字が久けている文が あるとしよう。日本語では，このような文脈に括いては欠字が「る」である頻度 の確率は非常に高い。そこで一字欠けていても完全な文は「明日は雨が降国|。」 であろうと予期しているから，欠字が「る」であるという情報を得ても，大して 情報を得たとは考㝋ない。つまり，文字が現われる頻度の確率が高ければ高い注 ど，得られる情報量は少ないと考光られる。ある文字の出現 i 飞関する情報 量 H(i)は，i 対する頻度の確率 P(i) 飞逆比例する。つまり，H(i) は P(i)の逆数 1
$\mathrm{P}(\mathrm{i})$ に比例する。ある専門的な理由から，情報理論では 2 を底とする対数 $\log _{2}$ を用いて情報量 $\mathrm{H}(\mathrm{i})$ を次のように定義する。

3.12 定義 $\mathrm{H}(\mathrm{i})=\mathbf{d f} \quad \log _{2} \mathrm{P}(\mathrm{i})$

この情報量の概念について特記すべきは次の二点である。

1. 構文論的概念である。

2. 統計的確率（頻度の確率）の概念に基づいている。

情報理論は記号を対象とするから記号論の一部とみなされ得るが, 記号論は, 記号の異同，記号の種類の異同，記号の配列順序というような記号相互の形式的 関係のみを問題とする構文論 (syntax) と, 記号と対象との間の指示関係を問題 とする意味論 (semantics) と，さらに記号と記号の使用者との関係を問題とする 語用論（pragmatics）とに分類されるが，情報理論は記号論としては構文論に属 する。また，情報理論は確率論を基礎としているので，確率論の一部とみなされ 得るが，確率論は，事象の頻度を問題とする統計的確率論と，命題の確証度を問 題とする論理的確率論 (帰納論理学, 帰納的確率論, 確率論理学ともいう) と, 
主観の確信度を問題とする主観的確率論とに分類されるが，情報理論は統計的確 率論に属する。

最近, 心理学に执いて心理的な情報の理論が発展してきているが，それは記号 論としては語用論に属し, 確率論としては, 少なくとも主観的確率論をもふくま ねばならない。カルナップとバー・ヒレルによって提唱された意味情報理論は, 記号論としては意味論に属し, 確率論としては論理的確率論に属する。

工学的な情報理論の情報量の定義3.12 亿対応する意味情報理論に括ける類似の 定義がある。

\subsection{3 定義 $\inf (\mathrm{S})=\mathbf{d f} \log _{2} \frac{1}{\mathrm{c}(\mathrm{S})}$}

この定義に括いて, “c ( S )”の代わりに“m(S)”を私いてもよい。命題 Sの 意味情報量 $\inf (\mathrm{S})$ は, $\mathrm{S}$ の論理的確率 $\mathrm{c}(\mathrm{S})$ 飞逆比例する。つをり, $\mathrm{c}(\mathrm{S})$ の 逆数 $\frac{1}{\mathrm{c}(\mathrm{S})}$ に比例する。たとえば, 図表 4 に関して, 分析命題 “ $\mathrm{A} \vee \sim \mathrm{A}$ ” の意

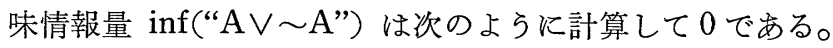

$$
\begin{aligned}
& \inf (\text { ( } A \vee \sim A ")=\log _{2} \frac{1}{\mathrm{c}(" \mathrm{~A} \vee \sim \mathrm{A} ")}=\log _{2} \frac{1}{\mathrm{~m}(\text { "A } \sim \mathrm{A} \text { ") }} \\
& \quad=\log _{2} \frac{1}{1}=\log _{2} 1=0
\end{aligned}
$$

3.14 inf ("A $\mathrm{A} \vee \sim \mathrm{A}$ ") $=0$

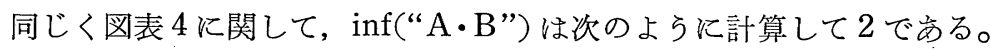

$$
\begin{aligned}
& \inf (“ \mathrm{~A} \cdot \mathrm{B})=\log _{2} \frac{1}{\mathrm{c}(“ \mathrm{~A} \cdot \mathrm{B} ")}=\log _{2} \frac{1}{\mathrm{~m}(“ \mathrm{~A} \cdot \mathrm{B} ")}=\log _{2} \frac{1}{1 / 4} \\
& \quad=\log _{2} 4=2
\end{aligned}
$$

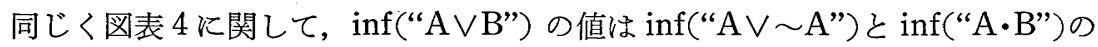
中間の值で, 計算して（数表を用いる） 0.412 を得る。

$$
\begin{gathered}
\inf (" A \vee B ")=\log _{2} \frac{1}{c(" A \vee B ")}=\log _{2} \frac{1}{m(" A \vee B ")}=\log _{2} \frac{1}{3 / 4} \\
=\log _{2} \frac{4}{3}=\log _{2} 4-\log _{2} 3=2-\log _{2} 3=0.412
\end{gathered}
$$

最後に，同じ図表 4 そ関し，矛盾命題“A・〜A”の意味情報量 $\inf (“ \mathrm{~A} ・ \mathrm{~A}$ ”) 
は次のように計算され，皇得る。

$$
\begin{aligned}
& \inf (" \mathrm{~A} \cdot \sim \mathrm{A} ")=\log _{2} \frac{1}{\mathrm{c}(" \mathrm{~A} \bullet \sim \mathrm{A} ")}=\log _{2} \frac{1}{\mathrm{~m}(" \mathrm{~A} \cdot \sim \mathrm{A} ")} \\
& =-\log _{2} \mathrm{~m}(“ \mathrm{~A} \sim \mathrm{A} ")=-\log _{2} 0=\infty
\end{aligned}
$$

一般に矛盾命題の意味情報量は無限大のであるとみなす。すると, 分析命題の 意味情報量は最小值で 0 であり, 矛盾命題の意味情報量は最大值でのである。綜 合命題の意味情報量は 0 とめとの中間值である。すなわち,

\section{$3.150 \leqq \inf (S) \leqq \infty$}

以上のように, 命題の意味情報量は工学的情報理論の情報量と類似の概念とし て定義できるのであるが，ある専門的な理由から，その概念のみでは十分に適切 な概念とはみなされず,ささらに, 次に考察する命題の内容測度 (content measure) の概念によって補わねばならないのである。

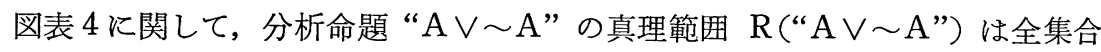
$\vee \theta$, 綜合命題 “ $A \vee B ”$ 真理範囲 $\mathrm{R}(“ \mathrm{~A} \vee \mathrm{B} ”)$ は $\left\{\theta_{1}, \theta_{2}, \theta_{3}\right\}$, 同じく綜合命題 “ $\mathrm{A}$.

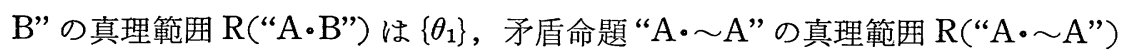
は空集合 $\wedge_{\theta}$ である。そこでこれらの真理範囲 $\mathrm{R}(\mathrm{S})$ といら集合の包含関係は次 のようになる。

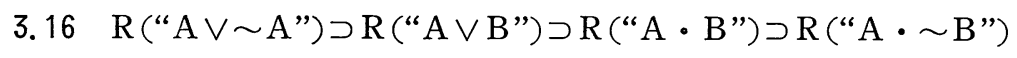

次に, 命題の内容 (content) の概念を定義しなければならない。適切ないくつ かの互いに多少異なった概念が定義できるが，ここでは最も簡単な次の定義だけ を示す。

\subsection{7 定義 $\operatorname{Cont}(\mathrm{S})=\mathbf{d f}-\mathrm{R}(\mathrm{S})$}

$\mathrm{S}$ の内容。Cont $(\mathrm{S})$ を $\mathrm{S}$ の真理範囲 $\mathrm{R}(\mathrm{S})$ の補集合 $-\mathrm{R}(\mathrm{S})$ として定義したので ある。

すると，同じ図表 4 に関し命題の内容—これも集合である—の包含関係は 次のようになる。

3.18 Cont ("A $\vee$ A") $\subset \operatorname{Cont}(" A \vee B ") \subset \operatorname{Cont}(" A \cdot B ") \subset \operatorname{Cont}(" A \cdot \sim A$ ") つまり, 分析命題の “ $A \vee \sim A$ ” の内容は綜合命題 “ $A \vee B$ ” の内容に包含され, 
“A $\vee \mathrm{B} ”$ の内容は同じく綜合命題 “A・B” の内容に包含され，さらに矛盾命題 “A・〜 A” の内容に包含される。一般に, 分析命題の内容はあらゆる命題の内容 に包含され，矛盾命題の内容はあらゆる命題の内容を包含する。命題の内容とい ら概念は包含関係によって順序づけられはするが，未だ計量概念ではない。計量 概念とするために，内容に測度を与兄る。測度を与えられた内容の概念は内容測 度とよび, 命題 $\mathrm{S}$ の内容測度 $\operatorname{cont}(\mathrm{S})$ を $\mathrm{S}$ の否定 $\sim \mathrm{S}$ の測度 $\mathrm{m}(\sim \mathrm{S})$ として定義 する。

\subsection{9 定義 $\operatorname{cont}(\mathrm{S})=\mathbf{d f} \mathrm{m}(\sim \mathrm{S})$}

すると, “A $\mathrm{A} \sim \mathrm{A} ”, “ \mathrm{~A} \vee \mathrm{B} ”, “ \mathrm{~A} \cdot \mathrm{B} ”, “ \mathrm{~A} ・ \mathrm{~A} ”$ の内容測度は，図表 4 を用いて上の定義によって計算すると次のようになる。

$$
\begin{aligned}
& \operatorname{cont}(" \mathrm{~A} \vee \sim \mathrm{A} ")=\mathrm{m}(" \sim(\mathrm{A} \vee \sim \mathrm{A}) ")=0 \\
& \operatorname{cont}(" A \vee B ")=m(" \sim(A \vee B) ")=1 / 4 \\
& \operatorname{cont}(" \mathrm{~A} \cdot \mathrm{B} \text { ") })=\mathrm{m}(" \sim(\mathrm{A} \cdot \mathrm{B}) \text { ") })=3 / 4 \\
& \operatorname{cont}(" \mathrm{~A} \cdot \sim \mathrm{A} \text { ") }=\mathrm{m}(" \sim(\mathrm{A} \cdot \mathrm{A}) ")=1
\end{aligned}
$$

一般に, 分析命題の内容測度は最小值で 0 であり, 矛盾命題の内容測度は最大 值で 1 である。綜合命題の内容測度は 0 と 1 との中間值である。すなわち,

3. $200 \leqq \operatorname{cont}(\mathrm{S}) \leqq 1$

これは前述の $3.150 \leqq \inf (\mathrm{S}) \leqq \infty$ に対応している。図表 4 亿関して $\inf (\mathrm{S})$ と $\operatorname{cont}(\mathrm{S})$ の大小関係を比較すると, 次のように対応する。

3. 21

$$
\begin{aligned}
& \inf (" A \vee \sim A ")<\inf (" A \vee B ")<\inf (" A \cdot B ")<\inf (" A \cdot \sim A ") \\
& \operatorname{cont}(" A \vee \sim A ")<\operatorname{cont}(" A \vee B ")<\operatorname{cont}(" A \cdot B ")<\operatorname{cont}(" A \cdot \sim A ")
\end{aligned}
$$

\section{4. 事実的情報と論理的情報}

前節で考察した意味情報理論を基礎として, 論理的情報(logical information) とよぶ新しい意味情報の概念を提案する。すべての分析命題の意味情報は等しく 最小值で 0 である。すなわち常識的に文字通りに同語反復な「AはAなり」とい ら分析命題も, 常識的には重要な多くの情報を伝える内容豊かな数学の定理も分 
析命題であって, 同じく意味情報量は 0 である。そのこと自体はパラドックスで るなければ奇妙でもない。第 2 節で考察したように，分析命題があらゆる可能な 事態に扣いて常に真となるという性質をもつ命題である限りは，すべての分析命 題は事実について情報を伝えず，事実的な内容が空であり，したがって，分析命 題の意味情報量ないし内容測度が 0 であるのは当然のことである。

だが，それにもかかわらず，分析命題の間で，その意味あるいは内容の相違に 応じて，意味情報あるいは内容測度の大小を考えることは合理的である。ただ， その意味情報量あるいは内容測度を, 従来の意味情報理論に括ける前述の意味情 報量あるいは内容測度と同種と解し，その延長線上に考えるとき矛盾し，不合理 となるのである。素朴反映論や先験論は，そのような不合理に抢ちいっている が，その意図はくまねばならない。本稿に怙ける私の提案は，カルナップが内包 と区別して提案した内包的構造（intensional structure）の概念を用いて，意味 情報理論を㧪張しょうと意図するもので，従来の意味情報の概念は，事実につい ての情報であるから事実的情報 (factual information) とよびかえ，新たに提案 される意味情報の概念は，論理についての情報であるから 論理的情報 (logical information)と名付ける。

まず，「同じ内包」あるいは「等しい内包」という概念を，ここでは命題につい てだけ定義する。命題の部分表現に適用される概念の定義は，ここでは紙数の関 係から，既知として前提する。(文献 3 参照)

4. 1 定義 $\mathrm{S}_{i}$ は $\mathrm{S}_{j}$ と同じ内包をもつ $=\mathbf{d f} \mathrm{S}_{i}$ は $\mathrm{S}_{j}$ と論理的に等値である。 ここで，「 $\mathrm{S}_{i}$ は $\mathrm{S}_{j}$ と論理的に等值である」は「 $\mathrm{S}_{i} \equiv \mathrm{S}_{j}$ は恒真である」として定 義されているとする。命題 Sが真であるといえるための必要かつ十分な条件を, 命題 $\mathrm{S}$ の真理条件 (truth-condition) といらが, $\mathrm{S}_{i}$ が $\mathrm{S}_{j}$ と「同じ真理条件をもつ」 ことと，「論理的に等值である」ことと，「 $\mathrm{S}_{i} \equiv \mathrm{S}_{j}$ は恒真である」ことと，「同じ

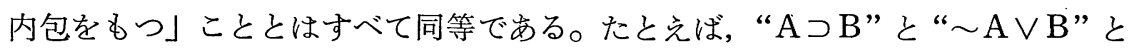

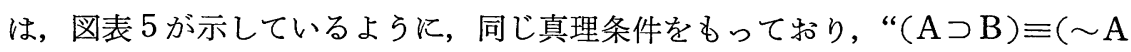
VB)”は恒真であるから，それらは論理的に等值であり，同じ内包をもつ。 前節で定義した命題 $\mathrm{S}$ の真理範囲 $\mathrm{R}(\mathrm{S})$ あるいは命題 $\mathrm{S}$ の内容 $\operatorname{Cont}(\mathrm{S})$ という 


\begin{tabular}{c|cc|c|c|c} 
& $\mathrm{A}$ & $\mathrm{B}$ & $\mathrm{A} \supset \mathrm{B}$ & $\sim \mathrm{A} \vee \mathrm{B}$ & $(\mathrm{A} \supset \mathrm{B}) \equiv(\sim \mathrm{A} \vee \mathrm{B})$ \\
\hline$\theta_{1}:$ & 真 & 真 & 真 & 真 & 真 \\
$\theta_{2}:$ & 真 & 為 & 偽 & 偽 & 真 \\
$\theta_{3}:$ & 偽 & 真 & 真 & 真 & 真 \\
$\theta_{4}:$ & 為 偽 & 真 & 真 & 真
\end{tabular}

図表 5

概念を用いて，次のように「同じ内包」を定義することもできる。

\section{2 定義}

1. $\mathrm{S}_{i}$ は $\mathrm{S}_{j}$ 同じ内包をもつ $=\mathbf{d f} \quad \mathrm{R}\left(\mathrm{S}_{i}\right)=\mathrm{R}\left(\mathrm{S}_{j}\right)$

2. $\mathrm{S}_{i}$ は $\mathrm{S}_{j}$ と同じ内包をもつ $=\mathbf{d f} \operatorname{Cont}\left(\mathrm{S}_{i}\right)=\operatorname{Cont}\left(\mathrm{S}_{j}\right)$

計量概念でない意味情報の概念に関して，「同じ意味情報」といら概念は次の ように定義できる。

4. 3 定義 $\mathrm{S}_{i}$ は $\mathrm{S}_{j}$ と同じ意味情報を伝える $=\mathbf{d f} \mathrm{S}_{i}$ は $\mathrm{S}_{j}$ と同じ内包をるつ。

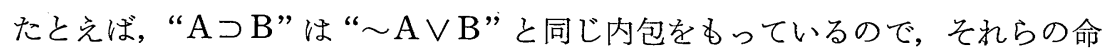
題は同じ意味情報を伝える。本節では「意味情報」の概念は拡張されるので, こ れをでの「意味情報」を「事実的情報」と言い換える。

4. 4 定義 $\mathrm{S}_{i}$ は $\mathrm{S}_{j}$ と同じ事実的情報を伝える $=\mathbf{d f} \mathrm{S}_{i}$ は $\mathrm{S}_{j}$ と同じ内包をも つo

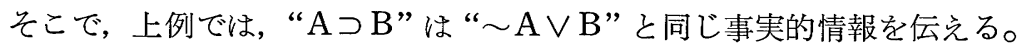

さて, ここでカルナップの「同じ内包的構造」あるいは「内包的に同型」とい ら概念の定義を考光る。厳密な定義は複雑であり，ここでは述べないが，(文献3， 58-59ページ参照) 文中の部分表現に関して「同じ内包」という概念が定義せられ ているとして，いち括う次のように定義することができよう。

4. 5 定義 $\mathrm{S}_{i}$ は $\mathrm{S}_{j}$ と同じ内包的構造をもつ $=\mathbf{d f} \mathrm{S}_{i}$ は $\mathrm{S}_{j}$ と同じ内包をもち, そして $\mathrm{S}_{i}$ と $\mathrm{S}_{j}$ 次次の二条件を満たす部分表現からなる。条件：1. $\mathrm{S}_{i}$ の部分 表現は $\mathrm{S}_{j}$ の部分表現に対し一対一の対応関係にある。2. $\mathrm{S}_{i}$ の部分表現はそ れに対応する $\mathrm{S}_{j}$ の部分表現と同じ内包をもつ。

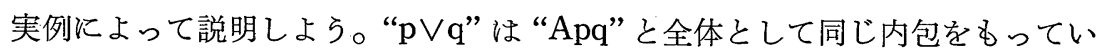
るだけでなく，前者の部分表現“p”，“V”，“q”はそれぞれ後者の部分表現“p”, 
“A”，“q”に一対一に対応し，しかもそれぞれ同じ内包をもっている。したがっ

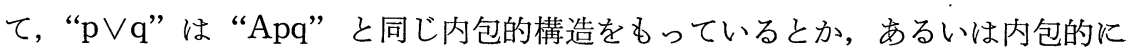
同型 (intensionally isomorphic) であるといわれる。“2+5>3”と“Gr〔Sum (II , V ), III]も同様に内包的に同型であるといってょいが，一対一に対応づける ところで複雑である。前者の部分表現 “2”, “十”, “5”, “>”, “3”を後者の “IIl, “Sum”, “V”, “Gr”, “III”に一対一に対応づけるのは容易だが，後者の 括弧とコンマに対応する記号は前者にはない。後者の記号の順序と括弧とコンマ の役割を果たすものは前者では, 記号の順序と記号の結合力の強さに関する言外 の暗黙の規約であるからである。したがって, 厳密な定義はずっと複雑となる。 かくして，「同じ論理的情報」という新しい概念の定義が得られる。

\section{6 定義 $\mathrm{S}_{i}$ は $\mathrm{S}_{j}$ と同じ論理的情報を伝える $=\mathbf{d f} \mathrm{S}_{i}$ は $\mathrm{S}_{j}$ と同じ内包的構} 造をもつ。

すべての分析命題は同じ内包をもつから，等しく事実的情報を伝えない一一 るいは空な事実的情報を伝える—が，しかし，必ずしも同じ内包的構造をもっ ているとは限らないので, 異なった内包的構造をもつ分析命題は異なった論理的 情報を伝える。

論理的情報に測度を与えて「論理的情報量」という計量概念を定義することは 困難であって，今後の課題にとどまるが，若千の示唆を与交よう。

(1) 人間は人間である。

（2）人間は理性的動物である。

(1)も(2)も分析命題であるとする。するといずれも事実的情報を伝えない。だ が, 異なった内包的構造をもっているから，異なった論理的情報を伝える。かり に(1)中の二番目の「人間」と(2)の「理性的動物」を対応づければ，(1)は(2)と 同じ内包をもつだけでなく, 同じ内包的構造をもつことになるから, 同じ論理的 情報を伝えるといえる。しかし，実際は，「理性的動物」は内部構造をもち，「理 性」という述語と「動物」といら述語を結合詞の「として」で結合した「理性的 そして動物」といら複合述語と解さねばならない。そこで，「人間」は「理性的動 物」と同じ内包をもってはいるが，異なった内包的構造をもっている。ところで， 
上述のように命題 (2)は，「理性的動物」という部分表現を別とすれば，(1)と同 じ論理的情報を伝えることになる。「人間」は「理性的動物」と同じ内包をもって いるから，(1)と（2）は同じ事害的情報を伝えるのであり，「理性的動物」は「人 間」よりも決して事実的情報量が大きくはなく，同一であるが，「理性的動物」の 方が「人間」よりも複雑な内包的構造をもっているので，より大きな論理的情報 量をもっていると考光ねばならない。したがって，(1)よりは(2)の方が論理的情 報量は大きいと解される。

一般に, 論理学の分析命題よりは数学の分析命題の方が論理的情報量は大きい と解されるが，それは数学の分析命題の方がいっそう複雑な内包的構造をもって いるからである。論理的情報に測度を与光，論理的情報量の概念を定義するなら ば，意味情報理論は従来の事実的情報の理論に新しい論理的情報の理 論が加わ り, 拡張一般化される。最後に，この新しい論理的情報の概念によって，以前提 案した「分析のパラドックス」の解法は補われねばならないことを付記して拉 く。(文献 5,108 -203ページ参照)

* 本稿の基礎となる思想の要旨は, 昭和 41 年 5 月 21 日, 教育大において開催された科 学基礎論学会41年度年会で「分析命題と論理的情報の概念」といら題で報告した。

\section{参考文献}

1. Y. Bar-Hillel, Language and Information, selected essays on their theory and application, 1964.

2. Y. Bar-Hillel and R. Carnap, "Semantic Information," Communication Theory (edited by W. Jackson), London, 1953.

3. R. Carnap, Meaning and Necessity, Chicage, 1947.

4. R. Carnap, Logical Foundations of Probability, Chicago, 1950.

5. 永井成男『分析哲学——言語分析の論理的基礎一—』弘文堂, 1959.

6. 永井成男『現代論理学の基礎一一推理と分析の論理——』有信堂, 1964.

7. 永井成男・黒崎宏『科学哲学概論』有信堂, 1967.

\section{筆者紹介：}

昭和19年, 東京医学歯学専門学校 (現, 東京医科歯科大学) 卒業。昭和24年, 早 稲田大学文学部哲学科卒業, 同大学院を経て, 現在, 東洋大学助教授, 千葉大学・ 早稲田大学・亜細亜大学講師。 
主要著書 :

『分析哲学』(弘文堂, 1959年), 『現代論理学の基礎』(有信堂, 1964年), 科学哲 学概論』(共著, 有信堂, 1967年), 『現代の論理学』(共著, 『『講座現代哲学入門』 第 2 巻, 有信堂, 1968年), 『現代の価値論と哲学』（共著,『講座現代哲学入門』第 4 巻, 有信堂, 1968年), その他。 